\title{
CRUDE PROTEIN IN DIETS OF EUROPEAN QUAILS
}

\section{PROTEINA BRUTA EM DIETAS DE CODORNAS DE CORTE}

\author{
Mariana Almeida Dumont ${ }^{1}$ \\ Sandra Regina Freitas Pinheiro ${ }^{*}$ \\ Jéssica Amaral Miranda ${ }^{1}$ \\ Fernanda Maria Pimentel Pinto ${ }^{1}$ \\ Patrícia Coelho Dias ${ }^{1}$ \\ Joerley Moreira ${ }^{1}$ \\ 1 Universidade Federal dos Vales do Jequitinhonha e Mucuri, Diamantina, MG, Brasil \\ * Author for correspondence - sandrafreitaspinheiro@gmail.com
}

\begin{abstract}
The aim of this study was to evaluate crude protein (CP) levels for European quails from one to 14, 14 to 28 and 28 to 42 days old. The experiment was carried out in a completely randomized experimental design, with five treatments and five replications. No significant effects of CP levels on weight gain and feed conversion from 1 to 14 days were observed, however quails fed $26 \%$ CP diets had lower feed intake. The CP levels from 14 to 28 days had significant effect on feed intake, weight gain and feed conversion. Maximum weight gain and minimum feed conversion were estimated for quails fed $24 \% \mathrm{CP}$. The CP levels had a significant effect on the traits studied in the final phase, highest weight gain and lowest feed conversion were estimated for quails fed $23 \% \mathrm{CP}$. No significant effects of CP levels on hot and cold carcass weights, breast weight, and thigh and drumstick weight were observed. The crude protein requirements for European quails from 1 to 14, 14 to 28 days and 28 to 42 days old are 26, 24 and 23\%, respectively, if the requirements of the first limiting amino acids are met.
\end{abstract}

Keywords: Amino acids, carcass yield, Coturnix coturnix, performance.

\section{Resumo}

O objetivo deste estudo foi avaliar níveis de proteína bruta (PB) para codornas europeias de um a 14, 14 a 28 e 28 a 42 dias de idade. O delineamento experimental foi inteiramente ao acaso, com cinco tratamentos e cinco repetições. Os níveis de PB não influenciaram o ganho de peso e a conversão alimentar das codornas de 1 a 14 dias de idade. Porém, a dieta contendo 26\% PB resultou em menor consumo da dieta. Os níveis de PB utilizados no período de 14 aos 28 dias influenciaram o consumo da dieta, o ganho de peso e a conversão alimentar, sendo o melhor ganho de peso e conversão alimentar estimados com dietas contendo $24 \%$ PB. Houve efeito significativo dos níveis de PB estudados, sobre o ganho de peso e conversão alimentar no período final, com máximos desempenhos estimados para codornas alimentadas com dieta com $23 \%$ PB. Não houve efeito dos níveis de PB sobre o peso da carcaça quente e peso da carcaça resfriada, peso do peito e da coxa mais sobrecoxa. As exigências de PB estimadas para codornas europeias são 26, 24 e 23\% para as fases de 1 a 14 dias, 
14 a 28 dias e 28 a 42 dias de idade, respectivamente, se forem atendidas as exigências dos primeiros aminoácidos limitantes.

Palavras-chave: Aminoácidos, Coturnix coturnix, desempenho, rendimento de carcaça.

Received on: January, $29^{\text {th }} 2014$.

Accepted on: August, $21^{\text {th }} 2017$

\section{Introduction}

The quality of the protein has great importance in quails diets rather, than the level in the diet, however, a food protein level offered for animals can not be underestimated, since several studies indicate effects on the parameters performance of quails ${ }^{(1)}$. Normally, the performance is increasing with the dietary crude protein increase. Otherwise, it will make the performance decrease and nitrogen wasted in intake excessive amounts of crude protein. It is not only a losing in benefit but also a polluting for environment ${ }^{(2)}$.

According to Jordão Filho et al. ${ }^{(3)}$, excess protein increases the oxidation of amino acid as source of energy and nitrogen excretion, whereas the deficiency increases the catabolism of tissue protein and fat from the poultry carcass. More importantly that diet must be formulated to contain the correct amount of crude protein for optimum performance. This strategy allow the chickens and quails to better utilize the dietary protein and to have no changes in performance traits by preventing the excessive excretion of amino acids and nitrogen, what would result in increased pollution of the environment.

Faced with few studies assessing the nutritional requirements for European quails and the discrepancy among the suggested values, this paper aimed to evaluate the effect of crude protein levels on the performance of European quails in the initial (from 1 to 14), growth (from 14 to 28) and final phases (from 28 to 42 days old) and on carcass weight and main cuts of European quails at 42 days of age.

\section{Material and Methods}

Three experiments were carried out at the Research Laboratory of Non-Ruminants of the Department of Animal Science in the Universidade Federal dos Vales do Jequitinhonha e Mucuri, in Diamantina, State of Minas Gerais, from July to September of 2011, using quails from the quail improvement breeding program of UFVJM. The experimental protocol was approved by the Animal Use Ethics Committee (CEUA) of the institution, with the protocol number: 005/2011.

The quails were evaluated in three phases, the initial (from 1 to 14 days old), growth (from 14 to 28 days old) and final (from 28 to 42 days old). The quails were always housed in three battery cages, made of galvanized wire $(60 \times 60 \times 35 \mathrm{~cm})$ equipped with trough type feeders and pressure cup drinker.

For the first experiment (initial phase) a total of 375 quails of one day old, no sexed, were allotted into five crude protein diets $(26,28,30,32$ and $34 \%)$ in a completely randomized experimental design with five repetitions and 15 quails per experimental unit. 
For the second experiment (growth phase), a total of 450 quails, no sexed, were allotted into five crude protein diets $(24,26,28,30$ and $32 \%)$ in a completely randomized experimental design with five repetitions and 18 quails per experimental unit.

And in the third experiment (final phase) a total of 300 quails, sexed, were allotted into five crude protein diets $(19,21,23,25$ and $27 \%)$ in a completely randomized experimental design with five repetitions and 12 quails per experimental unit (six males and six females).

The quails utilized in second and third experiment, were housed in protective circles under the floor, equipped with a feeder broiler small, pressure cup drinkers and heating system with infrared lamps (250W) until $14^{\text {th }}$ and $28^{\text {th }}$ days, respectively. The quails received a diet formulated so as to meet their nutritional requirements, as recommended by Silva $\& \operatorname{Costa}^{(4)}$.

The experimental diets were mainly comprised of corn and soybean meal and were formulated to meet the nutritional requirements of all nutrients, except crude protein (Tables 1, 2 and 3). The crude protein levels were obtained, mostly, by adjusting the amounts of corn and soybean meal. The essential amino acids levels (methionine, lysine, threonine and valine) were supplemented with industrial amino acids and followed the amino acids: lysine ratios next to those recommended by Silva \& Costa $^{(4)}$ for European quails. The composition of the ingredients followed those described by Rostagno et al. ${ }^{(5)}$. The water and food supplies were ad libitum throughout the experimental period. The maximum and minimum temperatures within the facilities were recorded daily with the use of three thermometers, one in each of the battery cages.

The minimum proportion of relative digestible amino acid to the lysine were $76 \%$ methionine + cystine and threonine, $21 \%$ for tryptophan, $90 \%$ for valine in initial phase. The growth phase were $74 \%$ methionine + cystine, $73 \%$ for threonine, $20 \%$ for tryptophan and $91 \%$ for valine. The final phase $69 \%$ metionina + cystine, $68 \%$ for threonine, $22 \%$ for tryptophan and $88 \%$ for valine, wich are close to recommendations Silva \& Costa $^{(4)}$.

Body weight and feed intake were recorded in each phase and mortality during the experimental period (date and the number of birds) was registered for subsequent correction of the feed intake.

The weight gain (g/bird), feed intake (g/bird) and feed conversion (grams of feed intake/grams of weight gain) were recorded in all the three experiments. Live body weight, hot carcass weight, cold carcass weight, breast weight and legs weight (thigh and drumstick) at 42 days of age were also recorded.

At 42 days of age four birds of each replication, two males and two females, according to the group average weight $( \pm 5 \%)$ were identified, stunned by cervical dislocation, slaughtered and bled for two minutes, after a fasting period of six hours. The scalding of the quails was held at a controlled temperature (from 53 to $55^{\circ} \mathrm{C}$ ) for 20 to 40 seconds. The birds were also eviscerated and the carcasses were weighed, without feet and head, and placed in a pre-cooling bath for 25 minutes, at $16^{\circ} \mathrm{C}$ and then cooled to $2^{\circ} \mathrm{C}$ for 24 hours. After 24 hours the main cuts were made and weighed.

All data were initially tested by normality and homogeneity of residual variances and analyzed the crude protein requirements. Were estimated by the first derivative of a second degree polynomial regression models and by fitting a broken line model. 
Table 1. Table 1. Percentage composition of experimental diets for initial phase (1 to 14 days of age) according to crude protein content.

\begin{tabular}{|c|c|c|c|c|c|}
\hline \multirow[b]{2}{*}{ Ingredients (\%) } & \multicolumn{5}{|c|}{ Crude Protein (\%) } \\
\hline & 26.00 & 28.00 & 30.00 & 32.00 & 34.00 \\
\hline Ground corn & 44.824 & 38.192 & 31.589 & 24.947 & 18.313 \\
\hline Soybean meal (45\%) & 48.302 & 53.825 & 59.307 & 64.841 & 70.365 \\
\hline Soybean oil & 2.915 & 4.025 & 5.124 & 6.238 & 7.349 \\
\hline Salt & 0.381 & 0.382 & 0.382 & 0.383 & 0.383 \\
\hline L-Threonine (98.5\%) & 0.204 & 0.215 & 0.237 & 0.248 & 0.260 \\
\hline L-Lysine $\mathrm{HCl}(78 \%)$ & 0.090 & 0.071 & 0.053 & 0.034 & 0.015 \\
\hline DL-Methionine ( $99 \%)$ & 0.412 & 0.450 & 0.498 & 0.536 & 0.573 \\
\hline L-Valine (99\%) & 0.187 & 0.201 & 0.215 & 0.223 & 0.236 \\
\hline Mineral supplement ${ }^{(1)}$ & 0.200 & 0.200 & 0.200 & 0.200 & 0.200 \\
\hline Vitamin supplement ${ }^{(2)}$ & 0.200 & 0.200 & 0.200 & 0.200 & 0.200 \\
\hline Dicalcium phosphate & 1.010 & 0.966 & 0.922 & 0.878 & 0.834 \\
\hline Calcitic limestone & 1.224 & 1.224 & 1.223 & 1.222 & 1.221 \\
\hline Antioxidant ${ }^{(3)}$ & 0.050 & 0.050 & 0.050 & 0.050 & 0.050 \\
\hline \multicolumn{6}{|l|}{ Calculated composition } \\
\hline Metabolizable energy $(\mathrm{kcal} / \mathrm{kg})$ & 2.900 & 2.900 & 2.900 & 2.900 & 2.900 \\
\hline Crude protein $(\%)$ & 26.00 & 28.00 & 30.00 & 32.00 & 34.00 \\
\hline Digestible methionine (\%) & 0.737 & 0.794 & 0.862 & 0.919 & 0.976 \\
\hline Digestible meth. + cystine (\%) & 1.080 & 1.160 & 1.250 & 1.330 & 1.410 \\
\hline Digestible lysine (\%) & 1.420 & 1.530 & 1.640 & 1.750 & 1.860 \\
\hline Digestible threonine (\%) & 1.080 & 1.160 & 1,250 & 1.330 & 1.410 \\
\hline Digestible tryptophan (\%) & 0.303 & 0.331 & 0.360 & 0.389 & 0.417 \\
\hline Digestible valine (\%) & 1.280 & 1.380 & 1.480 & 1.575 & 1.674 \\
\hline Available phosphorus (\%) & 0.320 & 0.320 & 0.320 & 0.320 & 0.320 \\
\hline Calcium $(\%)$ & 0.850 & 0.850 & 0.850 & 0.850 & 0.850 \\
\hline Sodium (\%) & 0.170 & 0.170 & 0.170 & 0.170 & 0.170 \\
\hline
\end{tabular}

(1) Per $\mathrm{kg}$ of product: manganese, $75 \mathrm{mg}$, iron, $50 \mathrm{mg}$, zinc, $70 \mathrm{mg}$, copper, $8: 50 \mathrm{mg}$, cobalt, $2 \mathrm{mg}$, iodine, $1.5 \mathrm{mg}$ and q.s.p. vehicle $1000 \mathrm{~g}$. (2) Per kg of product: vit. A, $12000 \mathrm{IU}$, vit. D3, $2200 \mathrm{IU}$, vit. and, $30 \mathrm{IU}$, vit. $B 1,2.2 \mathrm{mg}$, vit. B2, $6 \mathrm{mg}$, vit. B6 $3.3 \mathrm{mg}$, vit. B12, $16 \mathrm{mg}$, niacin, $2500 \mathrm{mg}$, pantothenic acid, $13 \mathrm{mg}$, vit. $\mathrm{K}, 2.5 \mathrm{mg}$, folic acid, $1 \mathrm{mg}$, selenium $0.12 \mathrm{mg}$, antioxidant, and $10 \mathrm{mg}$ q.s.p. vehicle $1000 \mathrm{~g} \cdot{ }^{(3)}$ Butylated hydroxytoluene. 
Table 2. Table 2. Percentage composition of experimental diets for growth phase (14 to 28 days of age) according to crude protein content

\begin{tabular}{|c|c|c|c|c|c|}
\hline \multirow[b]{2}{*}{ Ingredients (\%) } & \multicolumn{5}{|c|}{ Crude Protein (\%) } \\
\hline & 22.00 & 24.00 & 26.00 & 28.00 & 30.00 \\
\hline Ground corn & 56.691 & 49.903 & 43.146 & 36.442 & 29.755 \\
\hline Soybean meal (45\%) & 37.313 & 42.980 & 48.598 & 54.157 & 59.684 \\
\hline Soybean oil & 2.241 & 3.391 & 4.536 & 5.665 & 6.789 \\
\hline Salt & 0.381 & 0.381 & 0.382 & 0.383 & 0.383 \\
\hline L-Threonine (98.5\%) & 0.114 & 0.120 & 0.123 & 0.134 & 0.145 \\
\hline L-Lysine $\mathrm{HCl}(78 \%)$ & 0.064 & 0.025 & 0.000 & 0.000 & 0.000 \\
\hline DL-Methionine (99\%) & 0.266 & 0.304 & 0.343 & 0.376 & 0.423 \\
\hline L-Valine $(99 \%)$ & 0.147 & 0.151 & 0.166 & 0.175 & 0.193 \\
\hline Mineral supplement ${ }^{(1)}$ & 0.200 & 0.200 & 0.200 & 0.200 & 0.200 \\
\hline Vitamin supplement ${ }^{(2)}$ & 0.200 & 0.200 & 0.200 & 0.200 & 0.200 \\
\hline Dicalcium phosphate & 1.122 & 1.096 & 1.070 & 1.045 & 1.020 \\
\hline Calcitic limestone & 1.212 & 1.198 & 1.185 & 1.172 & 1.158 \\
\hline Antioxidant ${ }^{(3)}$ & 0.050 & 0.050 & 0.050 & 0.050 & 0.050 \\
\hline \multicolumn{6}{|l|}{ Calculated composition } \\
\hline $\begin{array}{l}\text { Metabolizable } \\
(\mathrm{kcal} / \mathrm{kg})\end{array}$ & 2.975 & 2.975 & 2.975 & 2.975 & 2.975 \\
\hline Crude protein (\%) & 22.00 & 24.00 & 26.00 & 28.00 & 30.00 \\
\hline Digestible methionine (\%) & 0.568 & 0.627 & 0.687 & 0.741 & 0.808 \\
\hline Digestible meth + cystine (\%) & 0.862 & 0.940 & 1.018 & 1.090 & 1.175 \\
\hline Digestible lysine (\%) & 1.120 & 1.220 & 1.330 & 1.457 & 1.584 \\
\hline Digestible threonine (\%) & 0.851 & 0.927 & 1.000 & 1.080 & 1.159 \\
\hline Digestible tryptophan (\%) & 0.243 & 0.271 & 0.298 & 0.325 & 0.352 \\
\hline Digestible valine (\%) & 1.060 & 1.150 & 1.249 & 1.342 & 1.442 \\
\hline Available phosphorus (\%) & 0.320 & 0.320 & 0.320 & 0.320 & 0.320 \\
\hline Calcium (\%) & 0.850 & 0.850 & 0.850 & 0.850 & 0.850 \\
\hline Sodium (\%) & 0.170 & 0.170 & 0.170 & 0.170 & 0.170 \\
\hline $\begin{array}{l}\text { (1) Per kg of product: manganese, } 75 \mathrm{~m} \\
1.5 \mathrm{mg} \text { and q.s.p. vehicle } 1000 \mathrm{~g} \text {. (2) Per } \\
\text { vit. } \mathrm{B} 1,2.2 \mathrm{mg} \text {, vit. } \mathrm{B} 2,6 \mathrm{mg} \text {, vit. B6 } \\
\text { vit. } \mathrm{K}, 2.5 \mathrm{mg} \text {, folic acid, } 1 \mathrm{mg} \text {, selenium } \\
\text { hydroxytoluene. }\end{array}$ & , iron, 50 & zinc, 70 & copper, 8 & $\mathrm{mg}$, coba & $2 \mathrm{mg}$, iod \\
\hline
\end{tabular}


Table 3. Percentage composition of experimental diets for final phase ( 28 to 42 day of age) according to crude protein content

\begin{tabular}{|c|c|c|c|c|c|}
\hline \multirow[b]{2}{*}{ Ingredients (\%) } & \multicolumn{5}{|c|}{ Crude Protein (\%) } \\
\hline & 19.00 & 21.00 & 23.00 & 25.00 & 27.00 \\
\hline Ground corn & 65.773 & 59.056 & 52.338 & 45.630 & 38.908 \\
\hline Soybean meal $(45 \%)$ & 29.588 & 35.171 & 40.759 & 46.318 & 51.910 \\
\hline Soybean oil & 1.713 & 2.845 & 3.975 & 5.108 & 6.241 \\
\hline Salt & 0.330 & 0.330 & 0.331 & 0.332 & 0.332 \\
\hline L-Threonine (98.5\%) & 0.027 & 0.028 & 0.029 & 0.032 & 0.031 \\
\hline DL-Methionine (99\%) & 0.144 & 0.177 & 0.210 & 0.245 & 0.276 \\
\hline L-Valine $(99 \%)$ & 0.073 & 0.080 & 0.083 & 0.100 & 0.106 \\
\hline Mineral supplement ${ }^{(1)}$ & 0.200 & 0.200 & 0.200 & 0.200 & 0.200 \\
\hline Vitamin supplement ${ }^{(2)}$ & 0.200 & 0.200 & 0.200 & 0.200 & 0.200 \\
\hline Dicalcium phosphate & 0.887 & 0.862 & 0.837 & 0.811 & 0.786 \\
\hline Calcitic limestone & 1.014 & 1.000 & 0.987 & 0.974 & 0.960 \\
\hline Antioxidant ${ }^{(3)}$ & 0.050 & 0.050 & 0.050 & 0.050 & 0.050 \\
\hline \multicolumn{6}{|l|}{ Calculated compositions } \\
\hline Metabolisable energy $(\mathrm{kcal} / \mathrm{kg})$ & 3.050 & 3.050 & 3.050 & 3.050 & 3.050 \\
\hline Crude protein (\%) & 19.00 & 21.00 & 23.00 & 25.00 & 27.00 \\
\hline Digestible methionine (\%) & 0.418 & 0.472 & 0.526 & 0.582 & 0.634 \\
\hline Digestible meth + cystine (\%) & 0.687 & 0.759 & 0.831 & 0.905 & 0.975 \\
\hline Digestible lysine (\%) & 0.893 & 1.021 & 1.149 & 1.277 & 1.405 \\
\hline Digestible threonine (\%) & 0.669 & 0.739 & 0.810 & 0.882 & 0.950 \\
\hline Digestible tryptophan (\%) & 0.205 & 0.232 & 0.259 & 0.287 & 0.314 \\
\hline Digestible valine (\%) & 0.872 & 0.963 & 1.050 & 1.150 & 1.240 \\
\hline Available phosphorus (\%) & 0.270 & 0.270 & 0.270 & 0.270 & 0.270 \\
\hline Calcium (\%) & 0.700 & 0.700 & 0.700 & 0.700 & 0.700 \\
\hline Sodium (\%) & 0.150 & 0.150 & 0.150 & 0.150 & 0.150 \\
\hline
\end{tabular}

(1) Per kg of product: manganese, $75 \mathrm{mg}$, iron, $50 \mathrm{mg}$, zinc $70 \mathrm{mg}$, copper, $8: 50 \mathrm{mg}$, cobalt, $2 \mathrm{mg}$, iodine, $1.5 \mathrm{mg}$ and q.s.p. vehicle $1000 \mathrm{~g}$. (2) Per kg of product: Vit. A, 12,000 IU, vit. D3, $2200 \mathrm{IU}$, vit. and, $30 \mathrm{IU}$, vit. $B 1,2.2 \mathrm{mg}$, vit. $B 2,6 \mathrm{mg}$, vit. B6 $3.3 \mathrm{mg}$, vit. B12, $16 \mathrm{mg}$, niacin, $2500 \mathrm{mg}$, pantothenic acid, $13 \mathrm{mg}$, vit. $\mathrm{K}, 2.5 \mathrm{mg}$, folic acid, $1 \mathrm{mg}$, selenium $0.12 \mathrm{mg}$, antioxidant, and $10 \mathrm{mg}$ q.s.p. vehicle $1000 \mathrm{~g}$. ${ }^{(3)}$ Butylated hydroxytoluene.

\section{Results and Discussion}

The average of the minimum and maximum temperatures values inside the barn were 28.3 and $38.5^{\circ} \mathrm{C}, 23.1$ and $31.8^{\circ} \mathrm{C}$ and 18.8 and $24.5^{\circ} \mathrm{C}$, for initial, growing and final phases, respectively. 
Significant linear effect $(\mathrm{P} \leq 0.05)$ of $\mathrm{CP}$ on feed intake of the quails in the initial phase, 1 to 14 days, $\left(\mathrm{FI}=1.329+95.048 \mathrm{CP}, \mathrm{R}^{2}=0.64\right)$ was observed (Table 4$)$. This effect can be explained by the deficiency in protein, even with supplementation of some essential amino acids, which led to an increase in feed intake to compensate for the protein deficiency and therefore, obtaining adequate levels of protein that meet your requirements. According to Diambra \& McCartney ${ }^{(6)}$ birds submitted to diets deficient in protein tend to increase consumption to compensate for this deficiency. Result similar to this work was reported by Corrêa et al. ${ }^{(7)}$, that evaluating CP levels in diets for European quails from 1 to 21 days of age, found that higher feed intake was observed for quails fed $31 \% \mathrm{CP}$ in diets. Teixeira et al. ${ }^{(8)}$ observed that $18.41 \%$ of CP in diet with $2550 \mathrm{kcal}$ of ME kg${ }^{-1}$ decreased feed intake of quails from 1 to 21 days of age and suggested that levels increased of $\mathrm{CP}$ and $\mathrm{ME}$, can occur increased in feed intake.

Table 4. Average feed intake (FI), weight gain (WG) and feed conversion (FC) in the initial phase (from 1 to 14 days), in function of crude protein levels of diets

\begin{tabular}{|c|c|c|c|c|c|c|c|}
\hline \multirow[b]{2}{*}{ Variable } & \multicolumn{5}{|c|}{ Crude Protein (\%) } & \multirow[b]{2}{*}{ P value } & \multirow[b]{2}{*}{ CV (\%) } \\
\hline & 26 & 28 & 30 & 32 & 34 & & \\
\hline FI (g) & 127 & 137 & 132 & 140 & 139 & 0.024 & 5.73 \\
\hline WG (g) & 78.54 & 84.39 & 80.35 & 82.73 & 83.55 & 0.496 & 6.25 \\
\hline $\mathrm{FC}(\mathrm{g} / \mathrm{g})$ & 1.621 & 1.621 & 1.652 & 1.694 & 1.663 & 0.539 & 6.39 \\
\hline
\end{tabular}

$\mathrm{CV}=$ Coefficient of variation

Despite the increased feed intake observed in quails fed with higher levels of crude protein, the crude protein levels did not influence $(\mathrm{P}>0.05)$ the quails weight gain and feed conversion. In this phase were supplemented with the amino acids lysine, methionine, threonine and valine, and the other for providing orally (corn and soyan meal). Thus, it is possible that feeds with lower protein levels, may have limited weight gain due to the limited amount of essential and nonessential amino acids in nonsupplement feed.

Teixeira et al. ${ }^{(8)}$ observed increase in the weight gain of European quails, with the increase of protein levels in the diets (from 18 to $26 \%$, with a range of $0.02 \%$ ) and $2700 \mathrm{kcal} \mathrm{ME} \mathrm{kg}^{-1}$. Otutumi et al. ${ }^{(9)}$ observed better performance for European quails fed 27\% CP in diets, from 1 to 14 days of age. While Silva et al. ${ }^{(10)}$ recommended $22.4 \% \mathrm{CP}$ in diets, supplemented with $1.1 \%$ methionine + cystine and $1.2 \%$ lysine for European quail from 1 to 21 days of age.

The CP levels affected $(\mathrm{P} \leq 0.05)$ feed intake, weight gain and feed conversion of meat quails from 14 to 28 days of age (Table 5). Increasing crude protein levels in the diets resulted in a reduction of feed intake, according to the equation: $\mathrm{FI}=386.133-5.505 \mathrm{CP}\left(\mathrm{R}^{2}=0.97\right)$. The diets content increased levels of crude protein may have presenting some imbalance of amino acids and that may have changed the feed intake in order to reduce it in terms of crude protein additions studied. According, Albino et al. ${ }^{(11)}$, the degree of deficiency or imbalance of amino acids in the feed results in various reactions of the birds, so that the feed intake is modified. 
Table 5. Average feed intake (FI), weight gain (WG) and feed conversion (FC) of European quails from 14 to 28 days in function of crude protein levels

\begin{tabular}{llllllll}
\hline & \multicolumn{7}{c}{ Crude Protein (\%) } \\
\cline { 2 - 8 } Variable & $\mathbf{2 2}$ & $\mathbf{2 4}$ & $\mathbf{2 6}$ & $\mathbf{2 8}$ & $\mathbf{3 0}$ & P value & CV (\%) \\
\hline FI $(\mathrm{g})$ & 262 & 258 & 246 & 230 & 221 & 0.001 & 8.69 \\
WG $(\mathrm{g})$ & 98.58 & 103.40 & 90.02 & 81.26 & 78.99 & 0.001 & 10.40 \\
FC $(\mathrm{g} / \mathrm{g})$ & 2.676 & 2.498 & 2.742 & 2.835 & 2.789 & 0.041 & 5.83 \\
\hline
\end{tabular}

$\mathrm{CV}=$ Coefficient of variation

The weight gain decreased linearly with the increase of crude protein of the diet according to the equation $\mathrm{WG}=167.991-2.993 \mathrm{CP}, \mathrm{R}^{2}=0.83$ (Figure 1 ). The result of a broken line model: $\mathrm{WG}=$ 78.996 - 3.197(29.36 - CP), $\mathrm{R}^{2}=0.84$ suggests quails fed $29.36 \% \mathrm{CP}$ in diets showed the lowest weight gain. Although weight gain decreased linearly with crude protein increased, this response pattern demonstrated that among the treatments, the results worst were observed at the higher crude protein levels $(26,28$ and $30 \% \mathrm{CP})$. The results have shown that the best response in weight gain were of the quails with diets of 22 and 24\% CP level. This result can be explained in part by lower feed intake obtained with higher levels of crude protein in diets and also due to excess protein and amino acids that are deaminated and nitrogen will be excreted in the form of uric acid by the birds. The process reflects in energy expenditure for the bird, so the excess of amino acids, or proteins do not contribute to improve the performance of the birds. In a study to evaluate different CP diet levels for European quail, Teixeira et al. ${ }^{(8)}$ observed that quails fed $23 \% \mathrm{CP}$ in diets and $3100 \mathrm{kcal} \mathrm{ME} \mathrm{kg}^{-1}$ showed better weight gain from 1 to 35 days of age. The observed reduction in weight gain due to an increase in diet protein level, according to Lima et al. ${ }^{(12)}$ is because the excess in amino acids can result in deviation of the energy for the process of excretion, reducing, thus, the energy to be used for the weight gain, besides environmental cost of increased nitrogen excretion.

However, Dowarah \& Sethi ${ }^{(13)}$ observed that the growth performance was higher in Japanese quail during starter (1 to 3 week) fed on high protein and high energy (27\% CP and $3000 \mathrm{Kcal} \mathrm{ME} / \mathrm{kg}$ ). Jordão Filho et al. ${ }^{(3)}$ observed that dietary requirement for protein gain was $30 \%$ higher for Japanese quails compared with the European, due to their being less efficient in the use of dietary protein to gain than European quails. The authors reported that use efficiency of protein for maintenance of metabolic processes and growth depends on the poultry genotype, in which poultry with the greatest potential for growth would be theoretically more efficient using the diet nutrients.

Corrêa et al. ${ }^{(14)}$ observed that meat type quails fed $27.9 \% \mathrm{CP}$ in diets had better weight gain from 15 to 21 days of age. Otutumi et al. ${ }^{(9)}$ also estimated maximum weight gain and better feed conversion for quails fed 27.43 and $26.35 \% \mathrm{CP}$ in diets, respectively, from 14 to 21 days of age.

The feed conversion increased with elevation in concentration of crude protein in diets, according to the linear equation: $\mathrm{FC}=2.022+0.0266 \mathrm{CP}, \mathrm{R} 2=0.46$ (Figure 2). Similary, the results have shown that the best response in feed conversion were of the quails with diet $24 \%$ of CP. A possible explanation for this is that for any excess of crude protein catabolism, more energy is deflected by the body to synthesize uric acid resulting in a decrease in weight gain. Excess protein increases the oxidation of amino acid as source of energy and nitrogen excretion, whereas the deficiency increases the catabolism of tissue protein and fat from the poultry carcass ${ }^{(3)}$. In a similar manner, Teixeira et al. ${ }^{(8)}$ observed better feed conversion with the lowest level (18\% of CP) and $3100 \mathrm{kcal} \mathrm{ME} \mathrm{kg}^{-1}$ from 1 to 35 days of age. 


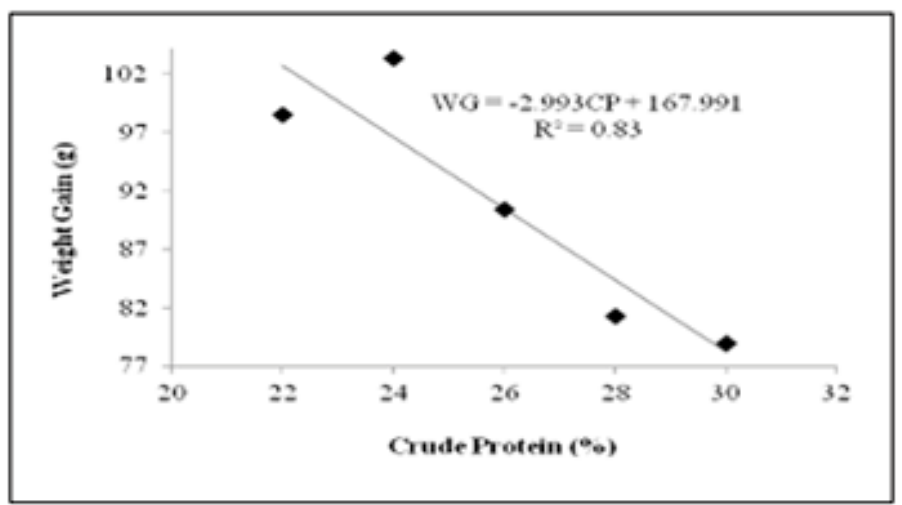

Figure 1. Weight gain in quails fed diets containing different crude protein levels in the period of 14 to 28 days of age.

The feed conversion increased with elevation in concentration of crude protein in diets, according to the linear equation: $\mathrm{FC}=2.022+0.0266 \mathrm{CP}, \mathrm{R} 2=0.46$ (Figure 2). Similary, the results have shown that the best response in feed conversion were of the quails with diet $24 \%$ of CP. A possible explanation for this is that for any excess of crude protein catabolism, more energy is deflected by the body to synthesize uric acid resulting in a decrease in weight gain. Excess protein increases the oxidation of amino acid as source of energy and nitrogen excretion, whereas the deficiency increases the catabolism of tissue protein and fat from the poultry carcass ${ }^{(3)}$. In a similar manner, Teixeira et al. ${ }^{(8)}$ observed better feed conversion with the lowest level $\left(18 \%\right.$ of $\mathrm{CP}$ ) and $3100 \mathrm{kcal} \mathrm{ME} \mathrm{kg}^{-1}$ from 1 to 35 days of age.

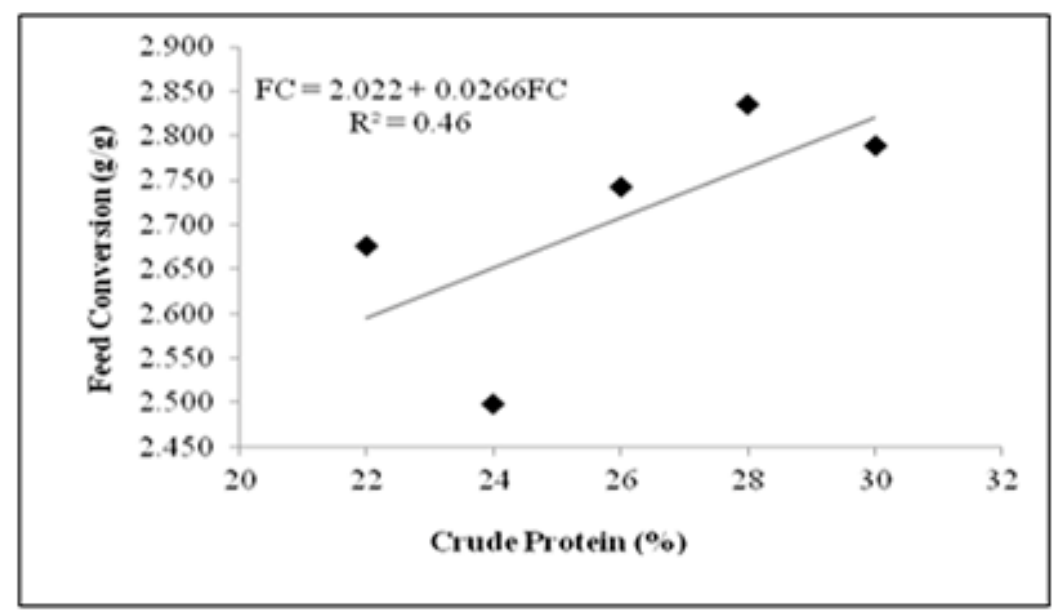

Figure 2. Feed conversion in quails fed diets containing different crude protein levels in the period of 14 to 28 days of age

The $\mathrm{CP}$ level of diets affected significantly $(\mathrm{P} \leq 0.05)$ all the performance traits in the final phase (Table 6). A significant quadratic effect of crude protein in the diets of the quails on the feed intake was estimated according to the following equation: $\mathrm{FI}=-1584.543+170.414 \mathrm{CP}-3.726 \mathrm{CP}^{2}, \mathrm{R}^{2}=0.90$. The maximum FI was estimated for quails fed $22.87 \% \mathrm{CP}$ in diet. This result may be due to the requirements of the birds amino acids, which increased feed intake in an attempt to meet your demand, when fed diets containing lower levels of crude protein. 
Table 6. Average feed intake (FI), weight gain (WG) and feed conversion (FC) of European quails from 28 to 42 days of age in function of crude protein levels of diets

\begin{tabular}{llllllll}
\hline & \multicolumn{7}{c}{ Crude Protein (\%) } \\
\cline { 2 - 8 } Variable & $\mathbf{1 9}$ & $\mathbf{2 1}$ & $\mathbf{2 3}$ & $\mathbf{2 5}$ & $\mathbf{2 7}$ & P value & $\mathbf{C V}$ \\
& & & & & & & $\mathbf{( \% )}$ \\
\hline FI $(\mathrm{g})$ & 311 & 347 & 355 & 361 & 293 & 0.020 & 11.97 \\
WG $(\mathrm{g})$ & 70.45 & 87.75 & 99.11 & 95.25 & 68.32 & 0.004 & 19.49 \\
FC $(\mathrm{g} / \mathrm{g})$ & 4.551 & 3.964 & 3.612 & 3.838 & 4.606 & 0.015 & 15.07 \\
\hline
\end{tabular}

$\mathrm{CV}=$ Coefficient of variation

The maximum weight gain in the present experiment was estimated for quails fed $23.06 \% \mathrm{CP}$ diet $\left(\mathrm{WG}=-877.282+84.686 \mathrm{CP}-1.836 \mathrm{CP}^{2}, \mathrm{R}^{2}=0.95\right)$. The optimum level estimated for increased feed intake and the estimated level to maximize weight gain of quails there that are very close, so to feed intake favored weight gain to a certain level. However, the lowest and the highest level of crude protein interfered negatively in weight gain, obtaining lower results (70.45 and $68.32 \mathrm{~g}$, respectively). The low growth of quails fed with lower levels of crude protein might be attributed to the limited amount of essential and nonessential amino acids. And those fed with higher crude protein levels may be due to muscle synthesis is genetically controlled, thus there is a limit on the daily protein deposition, regardless of their intake, as reported by Leeson cited by Sabino et al. ${ }^{(15)}$.

According to Fridrish et al. ${ }^{(16)}$, European quails fed $24.6 \% \mathrm{CP}$ in diets from 28 to 42 days of age showed highest weight gain, similar to the results observed in the present work. High levels of crude protein (30.6 and 28.29\%) were required for maximum feed intake and weight gain of meat quails from 28 to 35 days $^{(5)}$.

In this study quails fed $23.04 \% \mathrm{CP}$ in diets showed better feed conversion from 28 to 42 days of age $\left(\mathrm{FC}=34.608-2.691 \mathrm{CP}+0.0584 \mathrm{CP}^{2}, \mathrm{R}^{2}=0.98\right)$. Thus the best feed conversion was estimated for quails fed diets containing the level of $23 \%$ crude protein, and this level which also improves weight gain of birds.

Teixeira et al. ${ }^{(8)}$ observed lowest levels (18\% of CP and $2700 \mathrm{kcal} \mathrm{ME} \mathrm{kg}^{-1}$ ) showed better feed conversion of European quail from 1 to 35 days of age. This is different from the result obtained by Silva et al. ${ }^{(10)}$, who observed better feed conversion of meat quails fed diets with lower protein levels (19.2\%), suggesting that the protein in the diet from 22 to 42 days can be reduced without harm effect on feed intake. Otutumi et al. ${ }^{(9)}$ found a positive effect on feed conversion by increasing crude protein levels $(15,20,25$ and $30 \%)$ in diets of meat quails from 28 to 35 days.

No significant effects of diet CP level (P>0.05) on carcass traits were observed (Table 7). Similar results were also observed by Corrêa et al. ${ }^{(17)}$.

However, effect of different levels of crude protein (16 to $28 \%$, with a range of $0.03 \%$ ) on carcass traits of meat type quails at 42 days old, were studied by Cavalcante et al. ${ }^{(18)}$ that reported better result in carcass yield with $21.81 \%$ CP. A negative effect of higher dietary level of protein was obtained thigh + drumstick yield and breast yield of European quail. The authors reported that the excess of protein can be detrimental to the formation of muscle mass, by promote the increased catabolism of amino acids. 
Table 7. Average live weight (LW), hot carcass weight (HCW), cold carcass weight (CCW), breast weight (BW) and weight of thigh and drumstick (DTW) of meat quails at 42 days old in function of crude protein levels of diets

\begin{tabular}{llllllll}
\hline & \multicolumn{7}{c}{ Crude Protein (\%) } \\
Vyariable & $\mathbf{1 9}$ & $\mathbf{2 1}$ & $\mathbf{2 3}$ & $\mathbf{2 5}$ & $\mathbf{2 7}$ & P value & CV (\%) \\
\hline LW $(\mathrm{g})$ & 229 & 226 & 243 & 247 & 242 & 0.210 & 8.02 \\
HCW $(\mathrm{g})$ & 175 & 167 & 176 & 175 & 169 & 0.437 & 6.44 \\
CCW $(\mathrm{g})$ & 181 & 171 & 180 & 182 & 176 & 0.459 & 6.66 \\
BW $(\mathrm{g})$ & 76 & 71 & 75 & 74 & 70 & 0.563 & 7.00 \\
DTW $(\mathrm{g})$ & 41 & 42 & 43 & 43 & 43 & 0.428 & 8.67 \\
\hline
\end{tabular}

$\mathrm{CV}=$ Coefficient of variation

\section{Conclusions}

The levels of 26, 24 and $23 \%$ of crude protein provides, respectively, in the periods initial, growing and final, the best performance in birds, with no harm effect on the performance, if the requirements of the first limiting amino acids are met.

\section{Acknowledgements}

The authors would like to thank the FAPEMIG (Fundação de Amparo à Pesquisa de Minas Gerais), for funding the Project, the company Ajinomoto do Brasil Indústria e Comércio de Alimentos Ltda. for the donation of amino acids, and to professor Aldrin Vieira Pires (in memoriam) for the contribution in the work.

\section{References}

1. Oliveira EG, Almeida MIM, Mendes AA, Veiga N, Roça RO, Dias K. Avaliação do rendimento de carcaça de codornas para corte alimentadas com dietas com diferentes níveis protéicos. Archives of Veterinary Science. 2005;10(3):42-45.

2. Li YX, Wang YQ, Pang YZ, Li JX, Xie XH, Guo TJ, et al. The effect of crude protein level in diets on laying performance nutrient digestibility of yellow quails. International Journal of Poultry Science. 2011;10(2):110-112.

3. Jordão Filho J, Silva JHV, Costa FGP, Albino LFT, Melo TS, Lacerda, PB, et al. Requirement for maintenance and gain of crude protein for two genotypes of growing quails. Revista Brasileira de Zootecnia. 2012;41(9):2048-2054.

4. Silva JHV, Costa FGP. Tabelas para codornas japonesas e europeias - tópicos especiais, composição de alimentos e exigências nutricionais. Jaboticabal, SP: FUNEP; 2009. Portuguese.

5. Rostagno HS, Albino LFT, Donzele JL, Gomes PC, Oliveira RF, Lopes DC, et al. Tabelas brasileiras para aves e suínos: composição de alimentos e exigências nutricionais. Viçosa, MG: Universidade Federal de 
Viçosa; 2011. Portuguese.

6. Diambra OH, McCartney MG. The effect of low protein finisher diets on broiler males performance and abdominal fat. Poultry Science. 1985;64(10):2013-2015.

7. Corrêa GSS, Silva MA, Corrêa AB, Fontes DO, Santos GG, Lima Neto HR. Nível de proteína bruta para codornas de corte durante o período de crescimento. Arquivo Brasileiro de Medicina Veterinária e Zootecnia. 2008;60(1):209-217.

8. Teixeira BB, Pires AV, Veloso RC, Gonçalves FM, Drumond ESC, Pinheiro SRF. Desempenho de codornas de corte submetidas a diferentes níveis de proteína bruta e energia metabolizável. Ciência Rural. 2013;43(3):524-529.

9. Otutumi LK, Furlan AC, Martins EN, Garcia ELM, Ton APS, Monteiro AC. Efeito do probiótico sobre o desempenho, rendimento de carcaça e exigências de proteína bruta de codornas de corte. Revista Brasileira de Zootecnia. 2009;38(2):299-306.

10. Silva EL, Silva JHV, Jordão Filho J, Ribeiro MLG, Costa FGP, Rodrigues PB. Redução dos níveis de proteína e suplementação aminoacídica em rações para codornas européias (Coturnix coturnix coturnix). Revista Brasileira de Zootecnia. 2006;35(3):822-829.

11. Albino LFT, Silva SHM, Vargas Junior JG, Rostagno HS, Almeida e Silva M. Níveis de metionina + cistina para frangos de corte de 1 a 21 e de 22 a 42 dias de idade. Revista Brasileira de Zootecnia. 1999;28(3):519-525.

12. Lima MR, Costa FGP, Batista JDO, Oliveira SSM, Santos SCF. Impact of the feed metabolizable energy on protein and amino acids demand of Japanese quails. Global Journal of Animal Scientific Research. 2013;1(1):8-19 [cited $2016 \mathrm{Jan}$ ]. Available from: http://oaji.net/articles/2014/738-1396680402.pdf

13. Dowarah R, Sethi APS. Various dietary levels of protein and energy interaction on growth performance of white plumage japanese quails. Veterinary World [Internet]. 2014;7(6):398-402 [cited 2016 Jan]. Available from: http://www.veterinaryworld.org/Vol.7/June-2014/7.pdf

14. Corrêa GSS, Silva MA, Corrêa AB, Almeida V, Fontes DO, Torres RA, et al. Exigências de proteína bruta e energia metabolizável em codornas de corte durante a fase de crescimento. Arquivo Brasileiro de Medicina Veterinária e Zootecnia. 2007;59(2):488-494.

15. Sabino HFN, Sakomura NK, Neme R, Freitas ER. Níveis proteicos na ração de frangos de corte na fase de crescimento. Pesquisa Agropecuária Brasileira. 2004;39(5):407-412.

16. Fridrich AB, Valente BD, Felipe-Silva AS, Silva MA, Corrêa GSS, Fontes DO, et al. Exigência de proteína bruta para codornas européias no período de crescimento. Arquivo Brasileiro Medicina Veterinária e Zootecnia. 2005;57(2):261-265.

17. Corrêa GSS, Silva MA, Fontes DO, Corrêa AB, Euler ACC, Fridrich AB, et al. Efeito de diferentes níveis de proteína e energia sobre o rendimento de carcaça de codornas européias. Arquivo Brasileiro de Medicina Veterinária e Zootecnia. 2005;57(2):266-271.

18. Cavalcante DT, Lima RC, Costa FGP, Santos CS, Cardoso AS, Silva APB, et al. Características de carcaça de codornas europeias alimentadas com diferentes níveis protéicos. Revista Científica de Produção Animal. 2010;12(1):53-55. 